\title{
Management of exogenous intoxication by carbamates and organophosphates at an emergency unit
}

\author{
Sydney Correia leão ${ }^{1 *}$, José Fernandes de Araújo², Alessandro Rodrigues Silveira², Alex André Ferreira Queiroz ${ }^{3}$, \\ Maria Júlia Silveira Souto ${ }^{3}$, Rodrigo Oliveira Almeida ${ }^{3}$, Diego Carvalho Maciel ${ }^{3}$, Tânia Maria de Andrade Rodrigues ${ }^{4}$ \\ ${ }^{1}$ Physician - Resident in Pathology - Universidade Federal de São Paulo (Unifesp), São Paulo, SP, Brazil \\ ${ }^{2} \mathrm{MD}$, MSc - Health Sciences Post Graduate Program, Universidade Federal de Sergipe, Aracaju, SE, Brazil \\ ${ }^{3}$ Medical Student - Group of Molecular Anatomy, Universidade Federal de Sergipe, São Cristóvão, SE, Brazil \\ ${ }^{4} \mathrm{MD}, \mathrm{MSc}$, PhD - Parasitic Biology Post Graduate Program, Morphology Department, Universidade Federal de Sergipe, São Cristóvão, SE, Brazil
}

Study conducted at the emergency unit of the Hospital de Urgências de Sergipe Governador João Alves (HUSE), Aracaju, SE, Brazil

Article received: 9/27/2014 Accepted for publication: 5/4/2015 *Correspondence: Address: Rua Botucatu, 740 São Paulo, SP - Brazil Postal code: 04023-062 sydneyleao@hotmail.com

http://dx.doi.org/10.1590/1806-9282.61.05.440

Conflict of interest: none

\section{SUMmARY}

Objectives: to evaluate and indicate the procedure to be followed in the health unit, both for diagnosis and the treatment of acute exogenous intoxications by carbamates or organophosphates.

Methods: a descriptive study based on retrospective analysis of the clinical history of patients diagnosed with intoxication by carbamates or organophosphates admitted at the emergency unit of the Hospital de Urgências de Sergipe Governador João Alves (HUSE) between January and December of 2012. Some criteria were evaluated, such as: intoxicating agent; patient's age and gender; place of event, cause, circumstances and severity of the intoxication; as well as signs and symptoms of the muscarinic, nicotinic and neurological effects.

Results: seventy patients (average age: $25 \pm 19.97$ ) formed the study's population. It was observed that $77.14 \%$ of them suffered carbamate intoxication. However, organophosphate intoxications were more severe, with $68.75 \%$ of patients presenting moderate to severe forms. Suicide attempt was the leading cause of poisoning, with 62 cases ( $88.57 \%$ of total). Atropine administration was an effective therapeutic approach for treating signs and symptoms, which included sialorrhea $(\mathrm{p}=0.0006)$, nausea $(\mathrm{p}=0.0029)$ and emesis $(\mathrm{p}<0.0001)$. The use of activated charcoal was shown effective, both in combating the signs and symptoms presented by both patient groups ( $\mathrm{p}<0.0001$ ).

Conclusion: it is concluded that the use of atropine and activated charcoal is highly effective to treat the signs and symptoms developed by patients presenting acute exogenous intoxication by carbamates or organophosphates.

Keywords: carbamates, organophosphates, atropine, charcoal, cholinesterase inhibitors.

\section{INTRODUCTION}

The acute exogenous intoxications caused by anticholinesterase drugs, which include carbamates and organophosphates, has been a common and severe health problem at hospital emergency units, either by accidental ingestion in the case of children or due to suicide attempts among adolescents and adults. ${ }^{1,2}$

Organophosphates are chemical substances derived from phosphoric acid and its homologues, which induce the irreversible inhibition of acetylcholinesterase in patients exposed to such compounds, causing accumulation of acetylcholine at cholinergic synapses. This accumula- tion leads to weakness and fasciculation of the muscle, and disruption of neural transmissions in the central nervous system. ${ }^{3,4}$ Carbamates, derived from carbamic acid or Nmethylcarbamic acid, have a mechanism of action similar to that of organophosphates, but the chemical bond is completely reversible; therefore, when considering non-lethal doses, the assumed duration of the toxic effects is expected to be significantly shorter than that of organophosphate intoxication cases. ${ }^{5}$ Both classes of compounds present varying degrees of toxicity to humans, high volatility and low persistence in the environment, rendering their analysis and detection difficult. ${ }^{6}$ 
According to the American Association of Poison Control Centers, 2.4 million cases of poisoning were reported in 2004; $4.2 \%$ of them were induced by pesticides. ${ }^{7}$ In Brazil, the National Toxic-Pharmacological Information System (Sinitox) registered 2,506 cases of human poisoning induced by pesticides in $2009 .{ }^{8}$ Notification is not mandatory in the country, which is similar to North America, where data suggest that only half of the poisoning cases are reported. ${ }^{8,9}$

Patients intoxicated by cholinesterase inhibitors show muscarinic, nicotinic and neurological signs and symptoms, which vary according to dose and the exposure route to the toxic agent. ${ }^{10}$ It should be highlighted the appearance of bronchorrhea, sialorrhea, miosis, diarrhea, muscular fasciculation, seizures and cyanosis, which may evolve, in severe cases, to coma or death. ${ }^{10,11}$ It is known that, depending on the severity of the case, hospitalization with variable duration may be needed to monitor the clinical picture and the patient outcomes.

The therapeutic approach often employed in cases of intoxication by carbamates and organophosphates includes the use of atropine and activated charcoal. ${ }^{12}$ Atropine acts both in the central nervous system and the autonomic nervous system, functioning as an antagonist of acetylcholine. The administration route is intravenous or intramuscular, with the starting dose for adults being 1 to $2 \mathrm{mg}$ in carbamate intoxications, and 2 to $4 \mathrm{mg}$ in organophosphate intoxications. ${ }^{13}$ Administration may be repeated at intervals and adjusted to the clinical situation of the patient until the clinical picture is reversed or signs of atropine intoxication appear. ${ }^{14}$ On the other hand, activated charcoal acts by absorbing compounds, not only the ones still present in the intestinal lumen, but also the ones already absorbed by the intestine. ${ }^{13}$ The recommended doses are $1 \mathrm{~g} / \mathrm{kg}$ for children younger than one year, 25 to $50 \mathrm{~g}$ for children aged between one and twelve years, and 25 to $100 \mathrm{~g}$ for adolescents and adults. ${ }^{15,16}$

Given the importance and impact of this issue on Public Health, we carried out the epidemiological characterization of intoxication cases by carbamates and organophosphates in the emergency unit of the Hospital de Urgências de Sergipe Governador João Alves (HUSE), Brazil. We hereby seek to evaluate and indicate the procedure to be followed in the health unit both for diagnosis and treatment of acute exogenous intoxications.

\section{Methodology}

This is a descriptive study based on retrospective analysis of the clinical history of patients diagnosed with intoxication by carbamates or organophosphates admitted at the emergency unit of the Hospital de Urgências de Sergipe Governador João Alves (HUSE), between January and December of 2012, whose conditions were reported to the Center for Information and Toxicological Assistance of Sergipe (Ciatox-SE). This study was approved by the Ethics Committee of Tiradentes University (CEP/Unit 010308R) and all of its steps have been conducted in compliance with the Declaration of Helsinki.

For analysis purposes, we created a data collection sheet, modified from Moraes (1999). ${ }^{17}$ The parameters discussed in this survey instrument were: intoxicating agent; patient's age and gender; place of event, cause, circumstances and severity of the intoxication; signs and symptoms of the muscarinic, nicotinic and neurological effects.

The number of symptoms showed by patients at admission at the health unit was also evaluated, as well as the therapeutic conduct during hospital stay, with an emphasis on gastric lavage, atropine and activated charcoal. The length of hospital stay of these patients was also considered.

During the realization of this study, 79 cases of acute exogenous intoxication by cholinesterase inhibitors were reported to Ciatox-SE. Seventy patients met the inclusion criteria in this study. Cases with insufficient data for analysis were excluded from the sample. All physicians who provided initial care to patients in the emergency sector at the emergency unit of the Hospital de Urgências de Sergipe Governador João Alves (HUSE) signed an Informed Consent Form.

The statistical study included analysis of averages and percentages, and Pearson's correlation test, being considered statistically significant when the p value was less than 0.05 .

\section{RESULTS}

Seventy patients formed the study's population. It was observed that 54 (77.14\%) of them suffered carbamate intoxication and $16(22.86 \%)$ were victims of organophosphate poisoning. Patient age ranged between one and 75 years (average: $25 \pm 19,975$ years). $34.29 \%$ of them were between 11 and 20 years old, and $30 \%$ between 21 and 30 years of age. Regarding gender, 34 patients (48.57\%) were females, with ages between one and 49 years, and half of them were between 11 and 20 years of age; $36(51,43 \%)$ were males, $33.33 \%$ of which were between 21 and 30 years old, and only $5.56 \%$ over 50 .

Organophosphate intoxications were more severe, with $68.75 \%$ of patients presenting moderate to severe forms, against $42.59 \%$ of those caused by carbamates. 66 of the 70 cases occurred at home, with prevalence, in both forms, in the urban area. Suicide attempt was the lead- 
ing cause of poisoning, with 62 cases ( $88.57 \%$ of total), equal gender distribution, followed by eight cases (11.43\%) of accidental ingestion, $75 \%$ of which involved people aged $0-10$ years.

All patients had acute exogenous exposure to the toxic component, be it either organophosphate or carbamate. In $85.71 \%$ of cases, the toxic agent was ingested alone; in $10 \%$ of them, it was ingested with alcohol; in $2.86 \%$, with medication; and in $1.43 \%$ of cases, with food. Oral exposure to the toxic agents was the most common route $(98.75 \%)$ and, in $1.25 \%$ of cases, the toxic substance was inhaled.

55 patients $(78.57 \%$ of total) had at least one muscarinic symptom, 35 (50\%) had at least one nicotinic symptom and 48 (68.57\%) showed signs of central nervous system injury. 20 patients ( $28.57 \%$ of the sample) had some degree of breathing difficulty. The average number of signs and symptoms presented by victims of intoxication was $5.05 \pm 4.14$, and they were hospitalized, on average, for $2.94 \pm 5.45$ days. Among the therapeutic conducts, it was observed an average administration of $60.35 \pm 101.34 \mathrm{am}$ poules of atropine, $2.52 \pm 2.42$ gastric lavages and $1.04 \pm 2.19$ prescriptions of activated charcoal.

It was found that sweating $(\mathrm{n}=21)$ was a sign presented in association with other nine symptoms, whereas miosis $(n=26)$, sialorrhea $(n=26)$ and nausea $(n=32)$ were always concomitantly found with eight other symptoms, being usually greater the application of atropine and activated charcoal and greater the length of hospital stay for these patients. It was verified that nausea $(p=0.0041)$, emesis $(\mathrm{p}=0.0006)$ and tachycardia $(\mathrm{p}=0.006)$ were symptoms that prolonged the hospitalization, as shown in Figure 1.

Atropine administration was an effective therapeutic approach for treating the signs and symptoms presented by these patients, either in general, $\mathrm{p}<0.0001$, or to improve sialorrhea $(\mathrm{p}=0.0006)$, nausea $(\mathrm{p}=0.0029)$, emesis ( $\mathrm{p}<0.0001)$, anxiety ( $\mathrm{p}<0.0001)$, sweating $(\mathrm{p}=0.0124)$ or tachycardia $(\mathrm{p}=0.0025)$. Figure 2 shows the average number of atropine ampoules administered in the presence of each of the signs and symptoms reported above.

The performance of gastric lavage was not a statistically significant manner to treat any of the signs and symptoms investigated. On the other hand, the use of activated charcoal was shown to be relevant to our study, being effective both in combating the signs and symptoms in general ( $p<0.0001)$ and in the treatment of miosis $(\mathrm{p}=0.0386)$, nausea $(\mathrm{p}=0.0087)$, emesis $(\mathrm{p}=0.0025)$, anxiety $(\mathrm{p}=0.0011)$ and palpitations $(\mathrm{p}=0.0143)$. Figure 3 shows the average number of prescriptions of activated charcoal according to symptoms.

When correlated with the total number of symptoms detected in patients victim of intoxication; the number of atropine ampoules administered, the number of activated charcoal prescriptions and the amount of days in the intensive care unit were significant for the total sample $(\mathrm{n}=70)$, all with $\mathrm{p}<0.0001$.

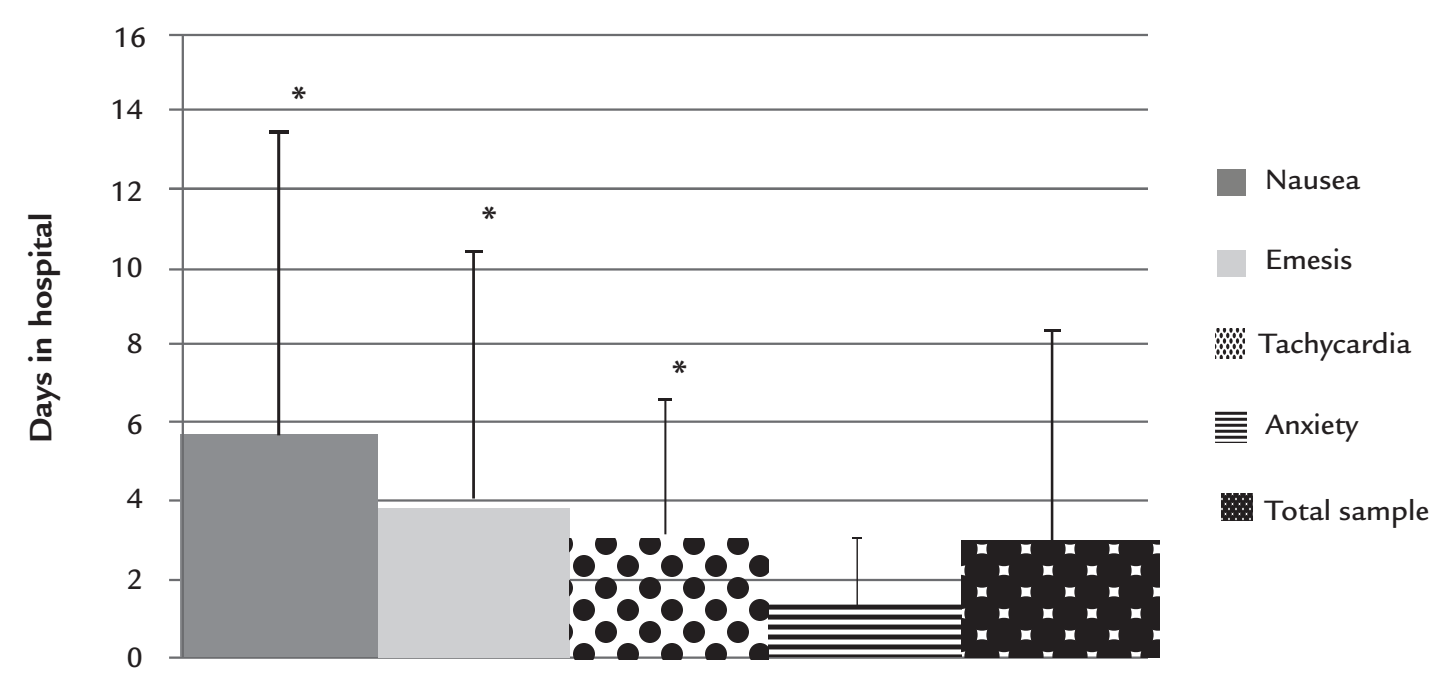

FIGURE 1 Average number of days in hospital according to the signs and symptoms of the patients ( ${ }^{*}$ nausea $p=0.0041 ;$ vomiting $p=0.0006$; tachycardia $\mathrm{p}=0.006$ ). 


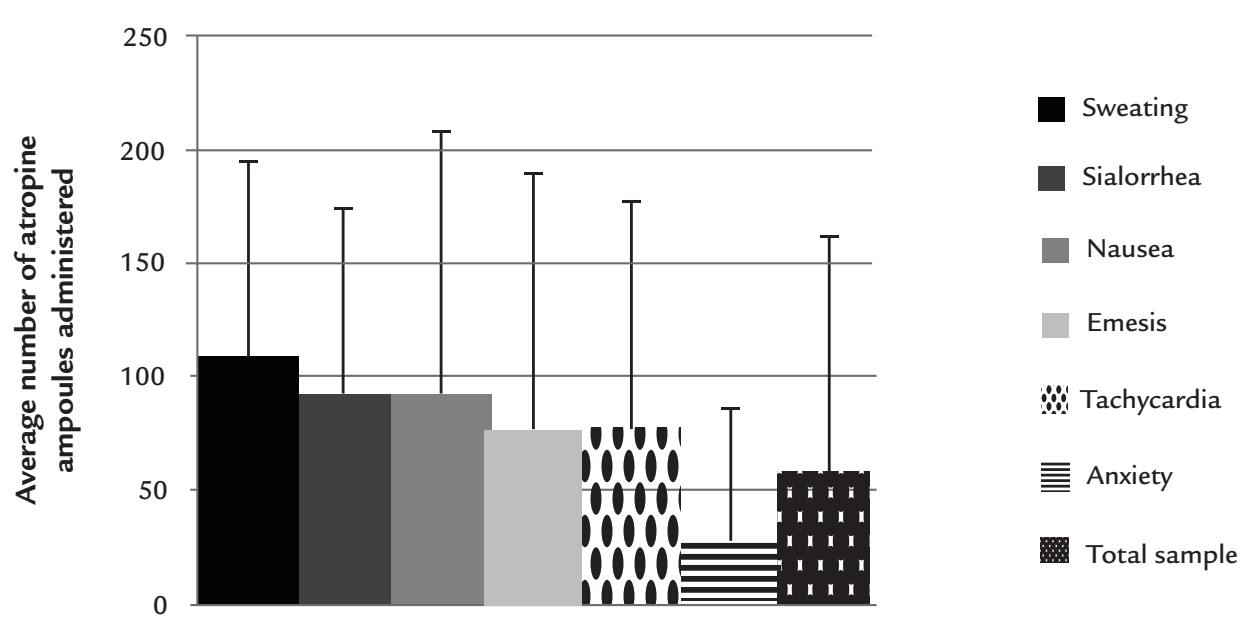

FIGURE 2 Average number of atropine ampoules administered according to patients' symptoms (sweating $p=0.0124$; sialorrhea $p=0.0006$; nausea $p=0.0029$; emesis $p<0.0001$; tachycardia $p=0.0025$; anxiety $p<0.0001$; total sample $p<0.0001$ ).

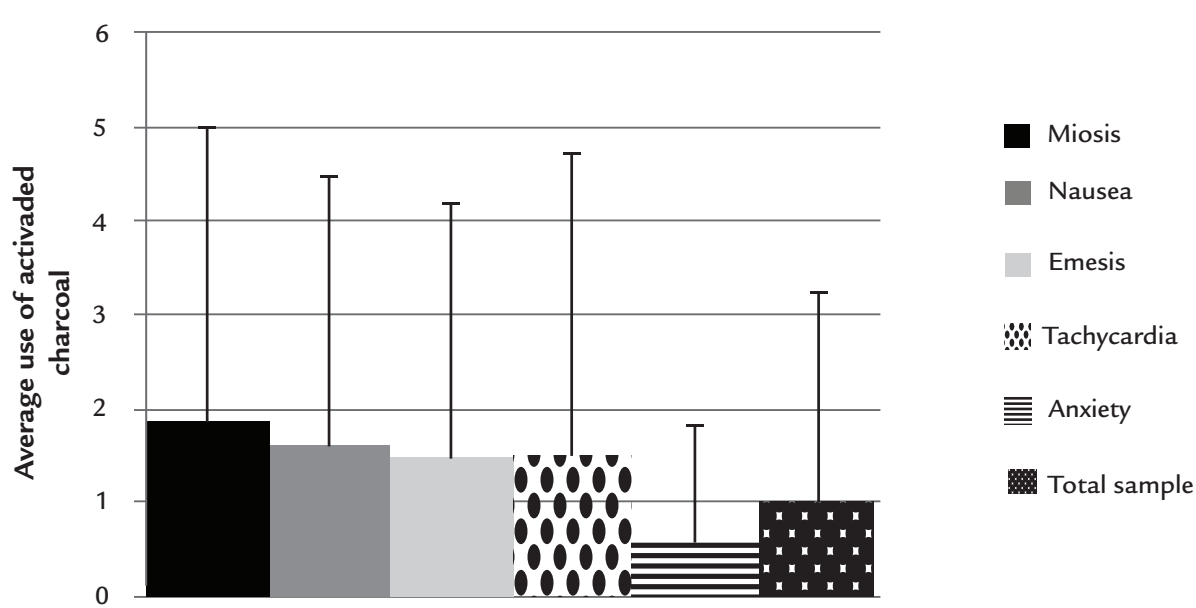

FIGURE 3 Average number of prescriptions of activated charcoal in the presence of specific signs and symptoms (miosis $p=0.0386$; nausea $p=0.0087$; emesis $p=0.0025$; tachycardia $p=0.0143$; anxiety $p=0.0011$; total sample $p<0.0001$ ).

\section{Discussion}

In the present study, carbamate intoxication predominated, with Aldicarb, a substance popularly known in Brazil as chumbinho (a carbamate pesticide), being the main cause. This fact reflects the easiness of acquisition of this product, which, despite being legally sold only for the primary sector, ${ }^{1}$ it is illegally purchased in Brazilian cities with the purpose of controlling rodent populations. It has proved to be a dangerous intoxication agent, often used in suicide attempts. The fact that adolescents and young adults have been the most affected by intoxication cases and the prevalence of suicide at- tempt in circumstances of contact with toxic agents are both data consistent with the current literature. . $^{211,18-20}$ Our study also showed that gender distribution has been approximately the same, affecting especially men between 21 and 30 and women between 11 and 20 years old. Indeed, it is known that a large number of men and young women attempt suicide, on account of emotional, mental, social or financial problems.

The high prevalence of intoxication occurring in the home (66 of 70 cases), with the highest incidence in the urban area, is in agreement with the works of Rebelo et al. ${ }^{19}$ and Vieira et al. ${ }^{21}$ This finding also alerts for cases of 
accidental poisoning, affecting, in our study, mainly children between zero and 10 years old. ${ }^{19,21}$

Cases of intentional intoxication, i.e. suicide attempts, and of accidental contact reflect the need to seek effective measures that restrict the access of general population to toxic agents which, although illegally in many cases, circulate freely in the third sector of Brazil. In this sense, the control of Aldicarb commercialization, for example, may be a factor that favors the reduction of intoxication cases in the country.

The signs and symptoms of the patients were typical of intoxication by carbamates and organophosphates, with miosis, sialorrhea, nausea, emesis, anxiety, sweating and tachycardia. ${ }^{10,11,21}$

The administration of atropine ampoules and the use of activated charcoal were found to improve the overall clinical picture of these patients, with $\mathrm{p}<0.0001$ for both atropine and activated charcoal. On the other hand, gastric lavage was not a statistically significant conduct $(\mathrm{p}=0.07)$, with regard to therapy. This finding is in agreement with the work of Vale, ${ }^{20}$ which shows that this practice is no longer recommended.

A detailed analysis of the therapeutic conduct administered to the 70 patients who formed our sample showed that atropine was effective in treating sialorrhea $(\mathrm{p}=0.0006)$, nausea $(\mathrm{p}=0.0029)$, emesis $(\mathrm{p}<0.0001)$, anxiety $(\mathrm{p}<0.0001)$, sweating $(\mathrm{p}=0.0124)$ and tachycardia $(\mathrm{p}=0.0025)$. On the other hand, when miosis $(\mathrm{p}=0.0386)$, nausea $(\mathrm{p}=0.0087)$, emesis $(p=0.0025)$ or tachycardia $(\mathrm{p}=0.0143)$ were present, more activated charcoal was needed for treatment. Both conducts proved to be statistically significant for the treatment of nausea, emesis, anxiety and tachycardia, but differ when it comes to sialorrhea, sweating and miosis. ${ }^{22,23}$

The data made it possible to observe that symptoms such as sweating $(\mathrm{n}=21)$, miosis $(\mathrm{n}=26)$, sialorrhea $(\mathrm{n}=26)$ and nausea $(\mathrm{n}=32)$ were always presented simultaneously with other symptoms: nine for sweating, and eight for the others. In such cases, the administration of atropine ampoules and the use of activated charcoal were usually greater. Anxiety $(n=31)$ appeared to be an uncommon symptom for patients in serious condition of intoxication, being more common in those who were not at risk of death. ${ }^{22-24}$

The average length of hospital stay in our study was $2.94 \pm 5.45$ days. It is known that this period varies according to the patient's condition and the severity of the intoxication. A detailed analysis of the occurrence of signs and symptoms individually showed that nausea $(\mathrm{p}=0.0041)$, emesis $(\mathrm{p}=0.0006)$ and tachycardia $(\mathrm{p}=0.006)$ prolonged the average length of hospitalization. The analysis of the signs and symptoms, together, corroborated this finding. ${ }^{24,25}$
The results of this work also revealed that, if the patient enters the hospital with two of the typical intoxication symptoms, the administration of atropine ampoules $(\mathrm{p}<0.0001)$ and the use of activated charcoal $(\mathrm{p}=0.0009)$ are indicated and there is no need to wait for the appearance of four or more symptoms. ${ }^{26}$

In general, our study also identified a statistically significant relation between the number of symptoms presented by the patient, the length of stay and the use of activated charcoal and atropine ampoules, suggesting that, in the presence of certain signs and symptoms, a longer hospital stay can be expected. Thus, the amount spent will be smaller and the reinstatement of the patient's wellbeing will happen sooner.

\section{Conclusion}

Based on these results, it is concluded that the use of atropine and activated charcoal is a highly effective therapeutic approach to treat the signs and symptoms presented by patients who are experiencing acute exogenous intoxication, being contraindicated the use of gastric lavage. Furthermore, it was shown that the existence of only two intoxication signs is a reliable indicator for therapeutic measures aimed at restoring the patient's general condition.

\section{Resumo}

Manejo de intoxicação exógena por carbamatos e organofosforados em uma unidade de emergência

Objetivo: avaliar e indicar os procedimentos a serem seguidos na unidade de saúde tanto para o diagnóstico como para o tratamento de intoxicações agudas exógenas por carbamatos ou organofosforados.

Métodos: estudo descritivo baseado na análise retrospectiva da história clínica de pacientes diagnosticados com intoxicação por carbamatos ou organofosforados admitidos em uma unidade de emergência, entre janeiro e dezembro de 2012. Foram avaliados alguns critérios, como: agente intoxicador; idade do paciente e gênero; causa de envolvimento, circunstâncias e gravidade da intoxicação; sinais e sintomas dos efeitos neurológicos muscarínicos e nicotínicos.

Resultados: setenta pacientes (idade média: 25 1 19,97 anos) formaram a população de estudo. Foi observado que 77,14\% deles sofreram intoxicação por carbamatos. Os casos mais graves foram intoxicados por organofosforados, com $68,75 \%$ dos pacientes apresentando formas moderadas a graves. Tentativa de suicídio foi a causa principal de envenenamento, com 62 casos (88,57\% do total). A administração de 
atropina foi uma medida terapêutica efetiva para tratamento de sinais e sintomas, como sialorreia $(\mathrm{p}=0,0006)$, náusea ( $p=0,0029)$ e êmese $(p<0,0001)$. O uso do carvão ativado mostrou efetividade para o combate dos sinais e sintomas apresentados por pacientes em geral $(\mathrm{p}<0,0001)$. Conclusão: o uso de atropina e de carvão ativado é uma medida terapêutica altamente efetiva para combater os sinais e sintomas apresentados por pacientes vítimas de intoxicação aguda exógena por carbamatos ou organofosforados.

Palavras-chave: carbamatos, compostos organofosforados, atropina, carvão ativado (Saúde Ambiental), inibidores da colinesterase.

\section{References}

1. Caldas LQA (coord.). Intoxicações exógenas agudas por carbamatos, organofosforados, compostos bipiridílicos e piretróides. Centro de Controle de Intoxicações de Niterói - Hospital Universitário Antônio Pedro Universidade Federal Fluminense. Niterói: Centro de Controle de Intoxicações de Niterói, 2000. 40p.

2. Bochner R. Perfil das intoxicações em adolescentes no Brasil no período de 1999 a 2001. Cad Saúde Pública. 2006; 22(3):587-95.

3. Aygun D. Serum acetylcholinesterase and prognosis of acute organophosphate poisoning. J Toxicol Clin Toxicol. 2002; 40:903-10.

4. Van Heel W, Hachimi-Idrissi S. Accidental organophosphate insecticide intoxication in children: a reminder. Int J Emerg Med. 2011; 4(1):32.

5. Leibson T, Lifshitz M. Organophosphate and carbamate poisoning: Review of the current literature and summary of clinical and laboratory experience in southern Israel. IMAJ. 2008; 10(11):767-70

6. Guiloski IC. Estudos in vivo e in vitro dos efeitos de pesticidas em peixes nativos. [Masters dissertation]. Curitiba: Universidade Federal do Paraná, 2009.

7. Saadeh AM, Farsakh NA, Al-Ali MK. Cardiac manifestations of acute carbamate and organophosphorate poisoning. Heart. 77:461-4.

8. Sistema Nacional de Informações Tóxico-Farmacológicas (Sinitox). Casos Registrados de Intoxicação Humana por Agente Tóxico e Trimestre. Brasil, 2009. Available from: http://www.fiocruz.br/sinitox_novo/media/tab05_ brasil_2009.pdf.

9. Warner M, Barnes PM, Finggerhut LA; Centers for Disease Control and Prevention/National Center for Health Statistics. Injury and poisoning episodes and conditions: National Health Interview Survey, 1997. Vital Health Stat 10. 2000; 202:1-38.

10. Oliveira MLF, Buriola AA. Gravidade das intoxicações por inseticidas inibidores das colinesterases no noroeste do estado do Paraná, Brasil. Rev Gaúcha Enferm. 2009; 30(4):648-55.

11. Ferreira A, Maroco E, Yonamine M, Oliveira MLF. Organophosphate and carbamate poisonings in the northwest of Paraná state, Brazil from 1994 to 2005: clinical and epidemiological aspects. Rev Bras Cienc Farm. 2008; 44(3):407-14

12. Bucaretchi F, Baracat ECE. Exposições tóxicas agudas em crianças: um panorama. J Pediatria (Rio J.) 2005; 81(5 Suppl):S212-22.

13. Oliveira RDR, Menezes JB. Intoxicações exógenas em Clínica Médica. Medicina, Ribeirão Preto 2003; 36:472-9.

14. Schvartsman C, Schvartsman S. Intoxicações exógenas agudas. J Pediatria. 1999; 75(Supl.2):S244-50.

15. Chyka PA, Seger D. AACT/EAPCCT position statement: single-dose activated charcoal. J Toxicol Clin Toxicol. 1997; 35:721-41.

16. Krenzelok EP, Vale JA, Chyka PA, Seger D. AACT/EAPCCT position paper: single-dose activated charcoal. J Toxicol Clin Toxicol. 2005; 43:61-87.

17. Moraes, ACL. Contribuição para o estudo das intoxicações por carbamatos: o caso do chumbinho no Rio de Janeiro. [Masters dissertation]. Fundação Oswaldo Cruz, Escola Nacional de Saúde Pública, 1999. 111p.

18. Pires DX, Caldas ED, Recena MCP. Intoxicações provocadas por agrotóxicos de uso agrícola na microrregião de Dourados, Mato Grosso do Sul, Brasil, no período de 1992 a 2002. Cad Saúde Pública. 2005; 21(3):804-14.

19. Rebelo FM, Caldas ED, Heliodoro VO, Rebelo RM. Intoxicação por agrotóxicos no Distrito Federal, Brasil, de 2004 a 2007 - Análise da notificação ao Centro de Informação e Assistência Toxicológica. Ciência \& Saúde Coletiva. 2011; 16(8):3493-502.

20. Vale JA. Position statement: gastric lavage. American Academy of Clinical Toxicology and European Association of Poison Centers and Clinical Toxicology. J Toxicol Clin Toxicol. 1997; 35:711.

21. Vieira LJES, Silva AND, Frota MA, Albuquerque VLM. Envenenamento por carbamato em crianças: estudo descritivo. RBPS. 2004; 17(4):193-9.

22. Nouira S, Abroug F, Elatrous S, Boujdaria R, Bouchoucha S. Prognostic value of serum cholinesterase in organophosphate poisoning. Chest. 1994; 106(6):1811-4

23. Agarwal S, Bhatnagar V, Agarwal A, Agarwal U, Venkaiah K, Nigam S, et al. Impairment in clinical indices in acute organophosphate insecticide poisoning patients in India. Int J Toxicol. 2007; 4(1).

24. Sam KG, Kondabolu K, Pati D, Kamath A, Pradeep Kumar G, Rao PG. Poisoning severity score, APACHE II and GCS: effective clinical indices for estimating severity and predicting outcome of acute organophosphorus and carbamate poisoning. J Forensic Leg Med. 2009; 16(5):239-47.

25. Davies JOJ, Eddleston M, Buckley NA. Predicting outcome in acute organophosphorus poisoning with a poison severity score or the Glasgow coma scale. Q J Med. 2008; 101:371-9.

26. Sungur M, Güven M. Intensive care management of organophosphate insecticide poisoning. Crit Care. 2001; 5:211-5. 